\title{
Exploration on the Coupling Construction Mechanism and Evaluation Model Between Professional and Industrial Clusters in Universities
}

\author{
Mei Chiao Lai \\ Department of Logistics Management and "Institute of Logistics and Supply Chain Management" \\ Fuzhou, China 350202
}

\author{
Wu Der Tsay \\ Research \& Development Center and "Fujian and Taiwan \\ Industrial Collaboration and Management Innovation \\ Research Center' \\ Fuzhou, China 350202
}

Yan Lin

Fuzhou University of International Studies and Trade Fuzhou, China 350202

\begin{abstract}
This paper aims to analyze professional cluster construction mechanism and the construction of evaluation system under the application-oriented transformation of universities. The structure of this paper is based on the international education certification standards, including the exploration of curriculum issues, vision and educational goals, curriculum construction, curriculum design approaches and teaching effectiveness, continuous evaluation and improvement of the curriculum. This study is based on the reform ideas of Chinese scholars and experts. It has followed the international education theory model and cited the experience of higher education in Taiwan. The research result is to construct a industrial college that combines the development of colleges and enterprises. Under the framework of the industrial college, the school-enterprise cooperation is deeply coupled. Starting from the goal of talent training, it would take the reform of personnel training model and the reconstruction of curriculum teaching system, and the reform of student-oriented teaching methods, the "dual teacher and dual ability" teacher construction and the construction of experimental training base, and the school-enterprise coupling transformation. The goal is to develop application-oriented talents that are in line with the needs of the enterprise. Finally, it should rebuild a set of professional cluster of applied talents training quality assessment index system integrating with international professional certification. Then, it could measure and analyze the coupling effect between professional clusters and industrial clusters. With this, it can improve the professional cluster construction. It highlights the connection between the application-based transition and the school-enterprise development to promote the quality assurance of education in line with international education certification standards. And it would become a new pattern of application-oriented transformation with Chinese characteristics.
\end{abstract}

Keywords-application-oriented transformation; professional cluster; industrial clusters; coupling; international education certification standards

\section{INTRODUCTION}

The basic idea of the application-oriented transformation is derived from the guidelines on the application-oriented transformation of the ordinary undergraduate colleges of the Ministry of Education on November 16, 2015. The goal is to ensure that schools can serve local economic and social development. And the colleges can cultivate applied technology-skilled talents through the integration of production and education [1]. However, in school-enterprise cooperation, schools and industries belong to different systems. How do professional clusters and industrial clusters cooperate with each other? How do they collaborate with each other? It is worth discussing. Marxism states that there are divisions of labor and collaboration in the development of human society and in the transformation of production methods, which embodies the concept of collaboration and triggers the first research motivation.

In 2015, the Fujian Provincial Government planned a linkage model of "subject-profession-industrial chain" [2]. Through effective interaction between disciplines, professional structures and industrial structures of higher education, regional economic and social growth and industrial structure transformation and optimization will be promoted. Also, it would improve the innovation of science and technology and the optimization and upgrading of the industrial structure. What kind of synergy effect does the professional cluster and industrial cluster produce? What is the effect? It has caused the second research motivation.

"The transformation and development of Chinese universities is in essence the supply-side structural reform of China's higher education", said Minister Yuan Guiren at the Fourth Session of the Twelfth National People's Congress. To get the bottom of something originates the mechanism issue. The science-humanities division teaching of colleges and universities is carried out. The biggest problem in the 
supply side of education is that in the face of the workplace of industry, it reflects the gap of academic use. And it is impossible to have the creative thinking of interdisciplinary integration. It is difficult to solve the real complex issues [3]. Applied talent cultivation really touches on the most needed things in the society, focusing on students' practical ability to apply knowledge. The talent supply and demand cannot be dislocated. Based on the principle of balanced supply and demand, industrial clusters need application-oriented talents. College teaching would train talents of professional cluster docking, highlight the teaching reform of professional cluster and improve the teaching quality and effectiveness evaluation. This would have become necessary topics for discussion and cause the third research motivation. For this reason, the purpose of this paper is to first explore how industrial clusters and professional clusters cooperate with each other in development. Second, it should clarify the mechanism and path of coupling between industrial clusters and professional clusters. Finally, it would develop a set of evaluation index system of training quality of applied talents in professional clusters that are integrated with international professional certification. And it can measure and analyze the effectiveness of professional cluster construction. Also, it would improve the construction of professional clusters.

\section{LITERATURE REVIEW}

This study reviews the integration of two institutions or two systems and the coupling operation and effects of industrial clusters and professional clusters, as well as international professional certification. Related theories and literature are as the following:

\section{A. Synergy Theory}

Due to internal conditions, founding time and history, enrollment scale, financial security, the external environment in the region and city, economic development, industrial conditions, as well as the different degree of integration of companies, the situation of running undergraduate colleges and universities is different. Synergy theory needs to be applied. Hermann Haken, professor and physicist at the University of Stuttgart in Germany, proposed synergetics in 1976, which is also known as "synergertios" or "coordination theory". It is a comprehensive discipline that has been widely used for more than a decade. Haken advocates that synergetics is a cross-discipline. The organization principle is that any system needs to accept the external environment for communication. It has the characteristic of openness. When the system communicates with the outside world, the material, information, and energy of the system are developed in an orderly manner. And it would explore the similarity of various systems from disorder to order and the feasibility of cooperation among subsystems in the system. Through their own internal synergy, it would spontaneously produce ordered structures in the functions. At the same time, it would produce the emerging disciplines of the synergy of various systems and synergetics mechanisms [4].

\section{B. Coupling Theory}

According to MBA Think-Tank Encyclopedia (2015), industrial ecosystem - coupling is the concept of physics. It refers to a phenomenon in which two or more systems interact with each other through various interactions. The economic management theory analyzes the coupling principle and finds the best combination of interactions between two or more industries. It promotes and supports each other. And then, it would coordinate the development. According to Karaomerioglu's opinion (1999), the basis of industrial coupling interaction model is the roundabout production process resulting from the division of labor. It uses the combination of theoretical research and empirical analysis to promote the level of innovation in universityindustrial cooperation and regional economic and social development. It is conducive to the development of industrial economy, the upgrading of university education and the development of national innovation [5] [6]. Li Jiangfan, Lv Zheng (2006)[7][8] think that the industrial coupling interaction model is a dynamic interaction process. Judging from the process of industrial interaction, the industrial boundaries are closely connected and overlapped. It provides outsourcing services in the upstream part of the value chain. It would penetrate each other in the midstream links. And it provides logistics, marketing and after-sales services in the downstream links.

\section{Industrial Clusters in Fujian Province}

In 1990, Mike Porter first proposed the word "industrial cluster" to analyze cluster phenomenon in the book "National Competitive Advantage". Industrial cluster refers that industries have the development in a certain circle. That is to say, it would form certain industrial chain within certain areas or regions. Different scales of industries with division and collaboration relationship that are concentrated in a certain area and various institutions, organizations, and other behavioral subjects related to the development represent a new type of spatial economic organization between the market and the hierarchy. The spatial accumulations of crisscross networks are closely linked. It is the industrial cluster effect.

\section{Professional Cluster of Undergraduate Colleges and Universities in Fujian Province}

The general higher education is based on disciplines. And its professional structure is based on the discipline structure. The current undergraduate education announced the principle of "taking into account of discipline classification with the professional posts group or industry as the main" in 2014. There are 19 major categories and 78 secondary classes. And it is a total of 532 professional subjects.

\section{E. The Linkage Policy of Industrial Chain and Professional Cluster in Fujian Province}

The Fujian Provincial Government implements the "Thirteenth Five-Year Plan for National Economic and Social Development in Fujian Province", "The Thirteenth Five-Year Plan for the Development of National Education", and "The Outline of the Medium and Long-term Education 
Reform and Development Plan for Fujian Province (20102020)" and the "Thirteenth Five-Year Plan" education development project. It is planned to promote the professional cluster of vocational education to dock with industrial clusters, and guide vocational schools to speed up industrial transformation and upgrading around Fujian province. For the needs of industries such as advanced manufacturing, strategic emerging industries, the internet industry, and modern service industries, we will focus on the industrial robots of planning and construction, integrated circuits, optoelectronics, creative design and other 10 major industries, and 200 professional clusters that are urgently needed.

\section{F. International Professional Certification Standards}

International professional certification is the main indicator of professional construction level. It is also an important starting point for standardizing professional training objectives, curriculum system, quality standards, resources guarantee and training process. The construction of domestic application-oriented professional clusters would take the average level of all qualified graduates to measure the quality of education. It is fully consistent with the "bottom line of thinking" of learning effect of all professional students emphasized by the international professional certification. The Ministry of Education of the
People's Republic of China and the Department of Education of Fujian province has promoted the education reform of international professional certification. China Engineering Education Professional Certification Association charged by the Ministry of Education officially joined the "Washington Agreement" on the International Mutual Recognition of Engineering Education Degree in June 2016. It becomes the promoter of international professional certification. And it can improve the quality of professional teaching. And the graduate degree has been recognized by the international organizations. The first batch of experimental units in Fujian province received international professional certification in 39 majors from 14 universities in the second half of 2016. Therefore, this research will also be based on the essence of international professional certification, and explore to build a evaluation system of professional cluster applicationoriented personnel training quality [9].

\section{RESEARCH METHODS}

\section{A. The Overall Structure of Research}

The overall structure of application-oriented transformation of undergraduate universities includes causes (structural changes), problems (solutions), transition paths (subsystem coupling innovation), and the construction of quality assessment system. (It is shown in "Table I").

TABLE I. APPLICATION-ORIENTED TRANSFORMATION MECHANISM AND EVALUATION FRAMEWORK FOR UNDERGRADUATE COLLEGES

\begin{tabular}{|c|c|c|c|}
\hline Causes/structural changes & Problems / Solutions & \multicolumn{2}{|c|}{ Transformation Path/Subsystem Coupling Innovation } \\
\hline $\begin{array}{l}\text { Causes } \\
\text { Industrial changes, technological } \\
\text { advances, innovations, gaps between } \\
\text { learning and use }\end{array}$ & $\begin{array}{l}\text { Problems } \\
\text { The imbalance and dislocation } \\
\text { docking of talent demand and } \\
\text { supply }\end{array}$ & \multicolumn{2}{|c|}{$\begin{array}{l}\text { Transformation Path } \\
\text { Government guidance, industrial participation, application- } \\
\text { oriented transformation of universities, training applied talents } \\
\text { service regional industries }\end{array}$} \\
\hline \multirow[t]{2}{*}{$\begin{array}{l}\text { structural changes } \\
\text { Industrial ecosystem changes } \\
\text { Increased demand for application- } \\
\text { oriented talent } \\
\text { flipped classroom } \\
\text { Production-teaching fusion textbook } \\
\text { update }\end{array}$} & \multirow[t]{2}{*}{$\begin{array}{l}\text { Solutions } \\
\text { With the interaction among the } \\
\text { government, production and the } \\
\text { study, the colleges and the } \\
\text { development of local industries } \\
\text { connect, communicate, and } \\
\text { closely link with each other, } \\
\text { leading to the coupling of } \\
\text { production and learning. }\end{array}$} & $\begin{array}{l}\text { Subsystem } \\
\text { Innovation } \\
\text { core }\end{array}$ & \multirow[t]{2}{*}{$\begin{array}{l}\text { Application-oriented } \\
\text { Transformation of University } \\
\text { integration of production and } \\
\text { education } \\
\text { professional } \\
\text { construction } \\
\begin{array}{l}\text { application-oriented } \\
\text { training talent }\end{array}\end{array}$} \\
\hline & & $\begin{array}{l}\text { Platform (government, } \\
\text { industry association support) }\end{array}$ & \\
\hline
\end{tabular}

\section{B. Research Methods}

This study will be based on the search, sorting, analysis, and refinement of the coupled symbiosis research results of professional cluster and regional industrial clusters under the application-oriented transformations of undergraduate universities. And it can draw on the essence of existing research and expand new domain. Through expert interviews and small-scale symposia, the school leaders in the pilot program of Ministry of Education, leaders of regional industries, experts and scholars are invited to conduct multiple interviews to develop research questions and framework design.

\section{RESEARCH RESULTS}

The in-depth study of the literature and the results of expert interviews revealed that the application-oriented transformation of colleges and universities was first to develop the industry and the school collaboratively, and to create an industrial college. Under the framework of the industrial college, the school-enterprise cooperation is deeply coupled. Starting from the goal of talent training, it would take the reform of personnel training model and the reconstruction of curriculum teaching system, and the reform of student-oriented teaching methods, the "dual teacher and dual ability" teacher construction and the construction of experimental training base, and the school-enterprise 
coupling transformation. The goal is to develop applicationoriented talents that are in line with the needs of the enterprise. Finally, it should rebuild a set of professional cluster of applied talents training quality assessment index system integrating with international professional certification. Then, it could measure and analyze the coupling effect between professional clusters and industrial

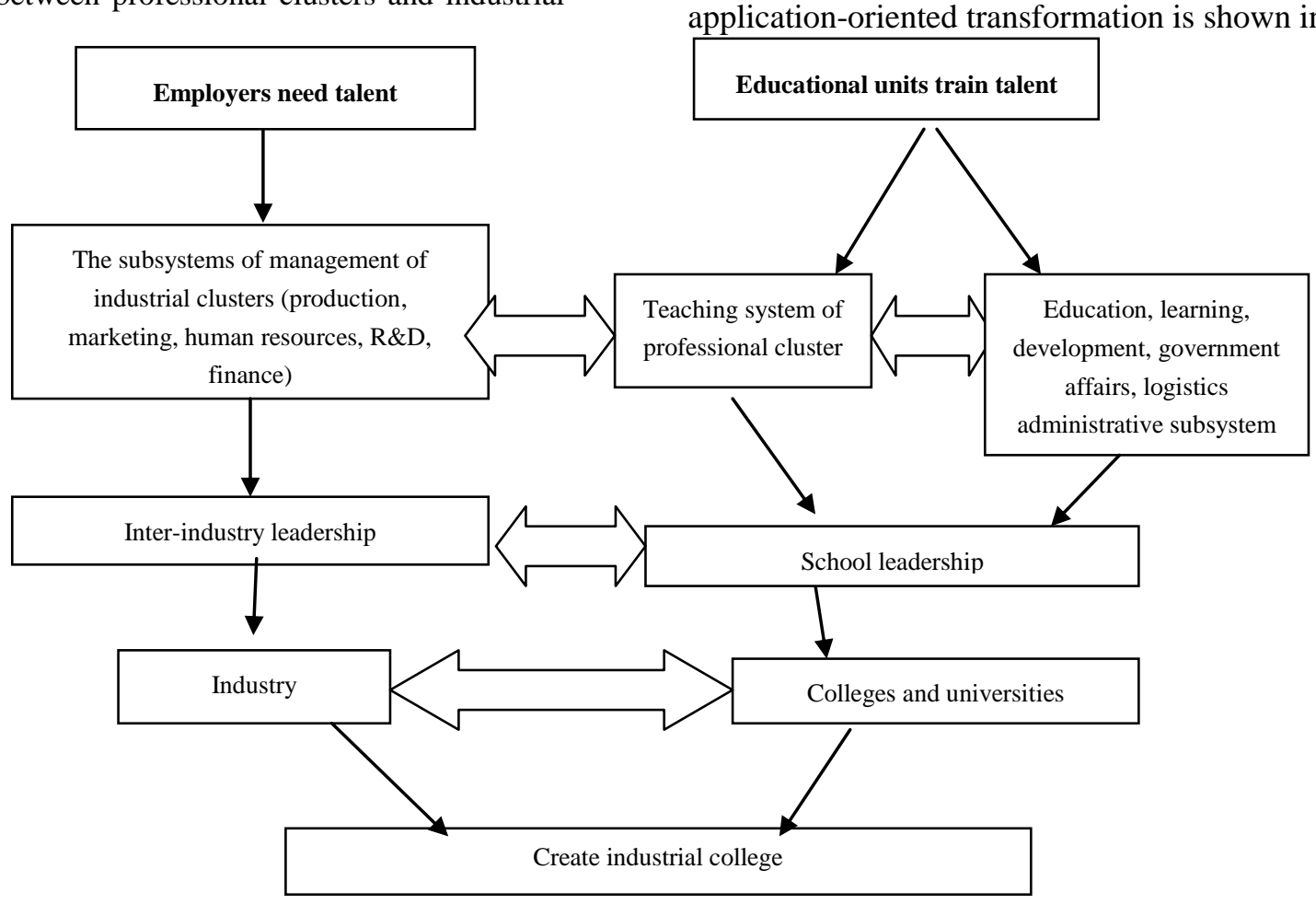

clusters. With this, it can improve the professional cluster construction. Then, it would show the explanation.

\section{A. Establishing the Industrial College, Promoting Coordinated Development of Industry and Schools}

The path of creating an industrial college under the application-oriented transformation is shown in "Fig. 1".

Educational units train talent

Fig. 1. Path figure of industrial college.

\section{B. Coupling Model of Industrial Clusters and Professional Clusters}

Coupling transformation model of professional cluster and industrial cluster takes the professional cluster of modern commerce service as an example. It first analyzes the employment needs of the corresponding industries (chains) and works out the talent training objectives together. And then, it should introduce the personnel training model of the school-enterprise cooperation and collaborative education. It would reconstruct the curriculum system, introduce studentoriented teaching model, construct "dual teacher and dual ability" teacher team and construct experimental training bases, etc. It is shown in "Table II".

TABLE II. IN-DEPTH COUPLING MODEL OF PROFESSIONAL PROFESSIONAL CluSTERs AND INDUSTRIAL CLUSTERS

\begin{tabular}{|c|c|c|c|c|c|}
\hline \multicolumn{2}{|c|}{ Industry demand side } & School-enterprise coupling & \multicolumn{3}{|l|}{ School supply side } \\
\hline Need the talents & Seeking talent & Use talents & \multicolumn{2}{|l|}{ talents } & cultivate people of ability \\
\hline \begin{tabular}{l}
\multicolumn{2}{l}{ superimposed } \\
industrial group \\
in four districts \\
of \\
province
\end{tabular} & $\begin{array}{l}\text { job responsibilities of } \\
\text { industry }\end{array}$ & $\begin{array}{l}\text { employment application } \\
\text { Ability of Employment Unit } \\
\text { position }\end{array}$ & $\begin{array}{l}\text { Five school-running cl } \\
\text { professional cluster }\end{array}$ & aracteristics of & $\begin{array}{lr}\text { Curriculum } & \text { Standards } \\
\text { Professional } & \text { Capability } \\
\text { Applied Talents } & \end{array}$ \\
\hline $\begin{array}{l}\text { Fuzhou New } \\
\text { District }\end{array}$ & $\begin{array}{l}\text { Marketing, computer, e- } \\
\text { commerce, logistics } \\
\text { management, engineering } \\
\text { service consulting, and } \\
\text { information consulting } \\
\text { cover the trade circulation } \\
\text { industry, modern logistics } \\
\text { industry, and other } \\
\text { industries. The industrial } \\
\text { cluster is developing } \\
\text { rapidly. }\end{array}$ & $\begin{array}{l}\text { International Economic and } \\
\text { Trade Literacy, International } \\
\text { Trade Technology } \\
\text { Capabilities, English, French, } \\
\text { Japanese Applied Capability, } \\
\text { Civil Engineering, } \\
\text { Engineering Management, } \\
\text { and Engineering Cost } \\
\text { Capability logistics, } \\
\text { Financial, anding and } \\
\text { information, accounting } \\
\text { art design capabilities }\end{array}$ & $\begin{array}{l}\text { International Business } \\
\text { Group, } \\
\text { Modern } \\
\text { service group, cultural } \\
\text { and creation industrial } \\
\text { cluster, engineering } \\
\text { consulting and service } \\
\text { group, } \\
\text { management financial } \\
\text { group }\end{array}$ & $\begin{array}{l}\text { Innovation } \\
\text { and } \\
\text { entrepreneurs } \\
\text { hip } \\
* \\
\text { Professional } \\
\text { Foreign } \\
\text { Language }\end{array}$ & $\begin{array}{l}\text { the core } \\
\text { indicators to match the } \\
\text { curriculum } \\
\text { Career Paths and Courses, } \\
\text { Employers Business-School } \\
\text { Business Research Course } \\
\text { Outline, } \\
\text { Standards, Curriculum } \\
\text { Methods, Assessment } \\
\text { Curriculum Planning System } \\
\text { (Evaluation, Certification) }\end{array}$ \\
\hline
\end{tabular}




\section{Construction of Appraisal Index System for Professional Cluster Application-Oriented Talents}

It should integrate the spirits of "Notification on application-oriented transformation of Universities", "Quality Assessment Index System" and "Technical Education Certification Standard" (International Professional Certification). It would construct a set of application-oriented professional cluster talents training quality assessment system for the transformation of university. As a standard of the coupling process of professional cluster industrial cluster and summative assessments, we will use the evaluation to promote the quality of professional cluster applicationoriented personnel training. The corresponding primary and secondary indicators of the evaluation system are shown in "Table III" below.

TABLE III. Professional Cluster Construction Quality Evaluation Index System

\begin{tabular}{|c|c|c|}
\hline Index & First Grade Indexes & Secondary Index \\
\hline $\begin{array}{l}\text { 1: Application- } \\
\text { oriented } \\
\text { transformation } \\
\text { goals, tasks and } \\
\text { effectiveness }\end{array}$ & $\begin{array}{l}\text { 1.1 Formulating overall transformation goals and tasks } \\
\text { 1.2 Formulating evaluation index system } \\
\text { 1.3 Decomposing professional cluster construction task } \\
\text { and pointer } \\
\text { 1.4 Statistical Phased Service Effectiveness }\end{array}$ & $\begin{array}{l}\text { 1.2.1 Supporting Demonstration Application-oriented } \\
\text { Transformation Goal Situations } \\
\text { 1.2.1 Establishing an evaluation index system to ensure that goals } \\
\text { are achieved } \\
\text { 1.3.1 Decomposing Phased Goals and Tasks of Professional } \\
\text { Clusters } \\
\text { 1.4.1 Achieving Phased Tasks to Serve Local Economic and Social } \\
\text { Demands and Statistical Analysis }\end{array}$ \\
\hline $\begin{array}{l}2: \quad \text { Application- } \\
\text { oriented } \\
\text { personnel } \\
\text { training program }\end{array}$ & $\begin{array}{l}\text { 2.1 Formulating professional cluster construction plan } \\
\text { and innovation and entrepreneurship education program } \\
2.2 \text { professional cluster Construction Information } \\
2.3 \text { to make the training according to the } \\
\text { "transformation" new program } \\
2.4 \text { business startups and innovation Education and } \\
\text { business startups and innovation ability }\end{array}$ & $\begin{array}{l}\text { 2.1.1 Formulation and Amendment Measures to Support Education } \\
\text { professional cluster Construction Project and Innovation and } \\
\text { Entrepreneurship Education Program } \\
\text { 2.2.1 Pilot Cases for the Construction of professional clusters } \\
\text { 2.3.1 students and grades of professional cluster } \\
\text { 2.4.1 business startups and innovation of statistics student and } \\
\text { Competition Project Awards }\end{array}$ \\
\hline $\begin{array}{l}\text { 3: } \quad \text { Curriculum } \\
\text { Reconstruction }\end{array}$ & $\begin{array}{l}\text { 3.1 Adjusting the professional cluster Curriculum } \\
\text { System } \\
\text { 3.2 Reconstruction of Application-oriented Talent } \\
\text { Cultivation Course } \\
3.3 \text { cultivating people of ability with the Integration of } \\
\text { Production and Education }\end{array}$ & $\begin{array}{l}\text { 3.1.1 Whether the professional cluster Course Adjustment Meets } \\
\text { Industry Needs } \\
\text { 3.2.1 design professional cluster curriculum construction } \\
\text { connotation } \\
\text { 3.3.1 linkage between professional cluster courses and enterprise } \\
\text { integration } \\
\text { 3.3.2 Industry leading reform meets industry demand }\end{array}$ \\
\hline $\begin{array}{l}4 \\
\text { oriented teaching } \\
\text { mode }\end{array}$ & $\begin{array}{l}\text { 4.1 School-enterprise cooperation curriculum design } \\
\text { 4.2 Case Teaching Innovation Model } \\
\text { 4.3 Problem-based Learning (PBL) } \\
\text { 4.4 Participant-centred learning methods }\end{array}$ & $\begin{array}{l}\text { 4.1.1 to Design the Number and Quality of the Course with School- } \\
\text { enterprises Collaboration } \\
\text { 4.2.1 Import Case Teaching Numbers, and compile Cases Number } \\
\text { 4.3.1. Importing Problem-oriented Course number } \\
\text { 4.4.1 Teaching methods changed from teacher-centered to student- } \\
\text { centered course }\end{array}$ \\
\hline $\begin{array}{l}\text { 5: Construction } \\
\text { of "dual teacher } \\
\text { and } \quad \text { ability" } \\
\text { teachers }\end{array}$ & $\begin{array}{l}\text { 5.1 Teacher Staff } \\
\text { 5.2 Teaching Team and Courses } \\
\text { 5.3 Research and Education Reform Project } \\
\text { 5.4 Patent Achievement Transformation Project }\end{array}$ & $\begin{array}{l}\text { 5.1.1 Distribution of academic qualifications, age distribution, } \\
\text { number of introduced teachers } \\
\text { 5.2.1 Number of Teaching Teams and Number of Open Courses } \\
\text { 5.3.1 Number of Key Courses and Scientific Research in Teaching } \\
\text { Reform } \\
\text { 5.4.1 Teacher's Patent Achievements and Technical Transformations }\end{array}$ \\
\hline $\begin{array}{l}\text { 6: Construction } \\
\text { and } \\
\text { implementation } \\
\text { of experimental } \\
\text { training base }\end{array}$ & $\begin{array}{l}\text { 6.1 Base Construction } \\
\text { 6.2. Having a laboratory } \\
\text { 6.3 Total experimental equipment } \\
\text { 6.4. Comparison of per capita equipment with that of } \\
\text { previous years }\end{array}$ & $\begin{array}{l}\text { 6.1.1 The number of bases } \\
\text { 6.2.1 Laboratory area, laboratory area per student } \\
\text { 6.3.1 The number of experimental software, total equipment, } \\
\text { 6.4. } 1 \text { Is the average per student equipment fee and internship fee } \\
\text { gradually increased? }\end{array}$ \\
\hline $\begin{array}{l}\text { 7: Measurement, } \\
\text { Analysis, and } \\
\text { Continuous } \\
\text { Improvement }\end{array}$ & $\begin{array}{l}\text { 7.1 Problem Feedback, the Next Phase of Work and } \\
\text { Continuous application-oriented transformation }\end{array}$ & $\begin{array}{l}\text { 7.1.1 Reviewing the Overall Transition Process of Undergraduate } \\
\text { Universities to Application-oriented Pilot Programs } \\
\text { 7.1.2 Reviewing the Coupling Mechanism and Approaches between } \\
\text { Professional and Industrial Clusters } \\
\text { 7.1.3 Reviewing the Mechanism of professional cluster Construction } \\
\text { Process }\end{array}$ \\
\hline
\end{tabular}

\section{CONCLUSIONS AND SUGGestions}

The cooperation and innovation between universities and industries can effectively promote the development of universities and industries. It is the core of the regional innovation system that meets the needs of regional economic and social development. This paper sorts out the applicationoriented transformation of undergraduate colleges, promotes the docking between vocational education professional cluster and industrial cluster, and guides the vocational colleges in the mechanism of industrial transformation and upgrading. It also clarifies whether the orientation of 
professional groups is clear. And it changes the original talents according to international professional certification norms, restructures curriculum teaching system, imports student-centered teaching methods, builds "dual teacher and ability" teacher team, and establishes experimental training base, etc. It would rebuild a set of professional cluster of applied talents training quality assessment index system integrating with international professional certification. Then, it could measure and analyze the coupling effect between professional clusters and industrial clusters. With this, it can improve the professional cluster construction. As a guideline for vocational colleges around industrial transformation, effective interaction between disciplines, professional structures and industrial structures of higher education is required to cultivate talents that meet the needs of regional industries.

The mechanism analysis of the application-oriented transformation of undergraduate colleges is still in the initial stage. It is mainly to investigate the needs of talents in the industry and the implementation process of school professional cluster construction from the perspective of schools. It is suggested that follow-up scholars can proceed from the local regional economic level. The establishment of professional cluster of undergraduate colleges and the improvement of the mechanism of industrial clusters can better meet the needs of the industry.

\section{REFERENCES}

[1] Ministry of Education, National Development and Reform Commission, Ministry of Finance. Opinions on Guiding Some Local Undergraduate Universities to Make Application-based Transformation. 2015-10-23 教育部 国家发展改革委 财政部关于 引导部分地方普通本科高校向应用型转变的指导意见, 教育部 国家发展改革委 财政部, 2015-10-23。

[2] [2016] No. 67) General Office of the People's Government of Fujian Province issued a notice on the "Thirteenth Five-Year Plan" for the development of education in Fujian Province. The "13th Five-Year Plan" for Education Development in Fujian Province, 2016-4. 闽政 办 (2016) 67 号) 福建省人民政府办公厅关于印发福建省“十三 五”教育发展专项规划的通知,福建省“十三五”教育发展专项规划, 2016-4。

[3] The Minister of Education, Yuan Guiren's answer to the reporter's question at the conference of the Fourth Session of the 12th National People's Congress (2016-3-10). 教育部长袁贵仁在十二届全国人大 四次会议记者会上答记者问实录，(2016-3-10）。

[4] Hermann Haken, Synergy theory, 5(2), 2018, http://doc.mbalib.com/tag/\%E5\%8D\%8F\%E5\%90\%8C\%E7\%90\%86 $\% \mathrm{E} 8 \% \mathrm{AE} \% \mathrm{BA}$

[5] Industrial Interaction - MBA, 2018, 5, 2, http://wiki.mbalib.com/wiki/\%E4\%BA\%A7\%E4\%B8\%9A\%E4\%BA $\% 92 \%$ E5\%8A\%A8

[6] Kang Peng, Wang Weiguang. Coupling research on universityindustry cooperative innovation[J].Technology Economics and Management, 2014. 康鹏, 王伟光. 大学一产业合作创新的耦合性 研究[J].技术经济及管理, 2014。

[7] Li Jiangfan, Bi doudou. Review of Foreign Production Service Industry Research[J]. Foreign Economy and Management 2004, (11):16-20 李江帆, 毕抖斗. 国外生产服务业研究述评[J]. 外国经济 与管理 2004, (11):16-20

[8] Lv Zheng, Liu Yong, Wang Qin. Strategic Choice of China's Production Services: Based on the Perspective of Industry Interaction [J]. China Industrial Economy 2006, (8): 5-12 吕政,刘勇, 王钦.中
国生产性服务业的战略选择:基于产业互动的研究视角[J].中国工 业经济 2006, (8): 5-12

[9] IEET Engineering and Technology Education Certification Standards and Data Preparation (November, 2015 2nd Workshop Courseware), 2018 , https://wenku.baidu.com/view/5b6c556ba1c7aa00b52acbb2.html IEET 工程及科技教育认证规范及资料准备(2015 年 11 月第 2 期 研习 会 课 件 ), 2018,5,2, 摘自 https://wenku.baidu.com/view/5b6c556ba1c7aa00b52acbb2.html 